\title{
Study on the Optimization of Practical Teaching for Applied Undergraduate in Independent Colleges ----- Take SY College as an Example
}

\author{
${ }^{1}$ Shiyuan College of Nanning Normal University. Nan Ning, Guangxi, PRC \\ ${ }^{2}$ Guangxi Science \& Technology Normal University. Lai Bin, Guangxi, PRC \\ ${ }^{3}$ Guangxi Science \& Technology Normal University. Lai Bin, Guangxi, PRC \\ a441443439@qq.com, b524229315@qq.com, ${ }^{c} 63152680 @ q q . c o m$
}

Leng Hongmei ${ }^{1, a}$, Li Shuwu $^{2, b^{*}}$, Dai Yanmei ${ }^{3, c}$

\begin{abstract}
According to the orientation of SY college: based on Guangxi and facing the whole country, the college should train the compound applied senior specialized talents with deep theoretical foundation, strong practical ability and innovative spirit. First, we should deeply analyze the definitions of "practical teaching" and "applied orientation" from cognition, then analyze the concrete practice of practical teaching under the guidance of the current talent training scheme of SY college. Finally, we find out the problems and put forward corresponding strategies and optimization schemes.
\end{abstract}

Keywords: independent colleges, talent training programs, practical teaching, optimization, applied orientation.

\section{PRACTICAL TEACHING IN SY INDEPENDENT COLLEGE}

Practical teaching is an effective way to consolidate theoretical knowledge and deepen theoretical understanding, an important link to cultivate high-quality engineering and technical personnel with innovative consciousness, and an important platform for integrating theory with practice, cultivating students to master scientific methods and improving practical ability. ${ }^{[1]}$ It is conducive to the improvement of students' literacy and the formation of correct values. For SY college, practice teaching is mainly as follows: probation, internship, innovation and entrepreneurship practice and social investigation.

The most distinctive features of the independent colleges are attached to the "mother school" resources. The management and the talent training model are basically as the whole teaching and management model of the "mother". SY's mother orientation is to build a modern university system, to build a high-quality faculty, to build a high-level talent training system, to enhance the ability to serve economic and social development, to enhance the level of international exchanges and cooperation, to cultivate cultural brands that mark the new image of the university, to build a high-quality service guarantee system, and to build the university into a high-level normal university with distinctive regional characteristics. ${ }^{[2]}$ From the analysis of the orientation of two schools, one should focus on "applied-orientation"; the other on "teacher-training". The orientation goal of running a school is different. Blindly modelling or copying mechanically,
SY college will cause the development to deviate from the orientation. At last, the characteristics are not prominent, which will certainly affect the graduation competitiveness of graduates.

\section{EXISTING PROBLEMS IN PRACTICE TEACHING IN SY COLLEGE}

\subsection{Unstable Core Unit of Practice Teaching}

Prior to the second half of 2014, the SY's overall teaching and administrative model relied on the mother body, and each department leader was basically selected from it. In short, SY college was the "epitome" of the mother body. After the second half of 2014, the mother body almost transferred the selected personnel back to the headquarters, resulting in an instant "fault" in the administrative posts of the SY College. In particular, it was evident that the Office of the Academic Affairs of SY College was headed by a Deputy Section Chief, who was responsible for examinations in this office, while the other administrative departments were similar. Although from the second half of 2014 to 2016, the corresponding personnel in each post of the SY academic Affairs Office have been relatively mature in their respective business. Because of the salary and other incentive system problems of the college, there is a basic "big blood exchange ". From 2016 to 2020, most of the posts of SY academic affairs office periodically have exchanged blood. Academic affairs office in SY college for more than two years of service are regarded as the old academic administration staff. 


\subsection{SY College Orientation Not Outstanding}

SY college's orientation is to highlight the "applied-orientation" At the beginning of the SY, relying on the "mother body" has built a set of teaching and administrative management systems. Although SY college has experienced the withdrawal of "mother" resources, the corresponding system and model are still retained. Moreover, because of the continuous "blood exchange" of the management team and the teaching management, SY is so hard to be able to "innovate ", in contrast, the basic focus is on stable teaching. In short, as long as there is a class, the basic operation of teaching is no problem. The rest is not a problem. So the practice teaching of majors are basically "herding sheep type" or "flowing type ", In summer or winter vocations, let students find a unit sealing on the documents. Practice whether as non-teachers or teachers, can be self-arranged. There is a part of the department arrangement. The Department of academic Affairs is basically responsible for issuing notices and receiving materials. Supervision can be void.

\subsection{Young Teachers Stand Out}

In the early stages of the development of the independent colleges, the resources are inseparable from the original mother school such as teachers, school buildings, network, book resources, teaching social resources, etc., but in fact, the independent college has not fully realized the true independence, or is in a difficult process of independence. [3] First of all, in terms of teachers, many independent colleges teachers are young people who have just graduated from schools, teaching 2-4 courses, sometimes even 5. Before the second half of 2014, there were many teachers with teaching experience who had come from the "mother school" . Later mostly young teachers who had just graduated have no teaching, working, and scientific research work experience, even no student management work experience and no school affairs management work experience. Therefore, the daily work of SY independent college will inevitably appear the phenomenon of quality decline. It has to focus on stabilizing everyday teaching.

\subsection{Inadequate Incentive System in SY College}

According to SY faculty, College teacher cost accounts for $24 \%$ of total expenditure, External peer evaluated SY teachers' salaries lower in the regional ranking of similar colleges and universities. High internal turnover rates and new teachers usually change in two years resulted in leaving ratio no more than $20 \%$ for new intake staff. Middle - level cadres are younger with Low titles. The income of the faculty during the winter and summer vacation does not exceed 1800 yuan, Only at the end of the year they will get 1000 yuan bonuses per person. Basic salary for teachers (1200-1600 yuan) plus class hours (after deducting 14 basic class hours) equal to around 3500 per month for staff. If it's a lecturer with more than 40 classes a week, the average monthly wage can exceed 5000 yuan, But every holiday, there's no class fee. The basic salary is between 1200 and 1600 yuan. It's so hard that every teacher can keep 20000-30000 savings a year. They also have no external promotion opportunities. As long as the need to pay the project will not be approved. Labor workloads contrast sharply with income. In the end, brain drain is hard to control.

\subsection{Nonstandard of Practice Teaching Evaluation}

SY College is divided into seven teaching departments. The Department of Education is the best. The students had high entrance scores than that of others. The students will have solid basic skills and the best graduate employment rate than that of others after graduation. This department was originally headed by a retired principal from a pre-school college. On the one hand, he was trusted by the principal investors of the college; on the other hand, the department under his jurisdiction followed his mature management system in the former school experience. In short, relying mainly on the retired principal's humanistic care for young people and compared with other departments, the staff flow in the Department of Education was less. No matter from daily teaching to practical teaching was orderly, so the students in the Department of Education had solid foundation and were favored by employers. Because of the great changes in the leading bodies and teachers of other departments, internship and probation are basically carried out in accordance with the original talent training program, and they are more trapped in the construction of practical teaching facilities and carry out other off-campus cooperation without passion, which can only become a mere formality in the end.

\section{OPTIMIZING COUNTERMEASURES OF PRACTICE TEACHING IN SY INDEPENDENT COLLEGE}

According to the above analysis of the problems of the SY Independent College, this paper puts forward the following optimization countermeasures.

\subsection{Strengthening the Top Level Design of Practical Teaching Management}

3.1.1. The top-level managers from SY college design the construction of four-level ability progressive practice teaching system based on the applied orientation. Taking the cultivation of innovative practical ability as the main line, the school creates a four-level progressive practical teaching system of basic skills, comprehensive skills, 
vocational skills and innovative practical ability, and systematically trains students to comprehensively use knowledge, theory and technology to analyze and solve problems faced in practical work.[4]

\subsubsection{The college increases the investment of} construction of school teaching and practical teaching facilities, and actively introduce out-of-school enterprises to form "enterprises in the school", introduce excellent teachers and industry experience from enterprises, and jointly formulate talent training programs to effectively reflect the applied undergraduate.

3.1.3. The system carries out practice according to professional or professional cluster system, and applies information system to assist the process management of practice. For example: freshman and sophomore students open cognitive practice so that students have a certain understanding of their future professional posts, and they have targeted to set their own learning goals and university planning; junior students open field follow-up study so that students make full use of the basic knowledge laid down in the first and second year of college life, letting them touch with preliminary experience of the actual post; senior students open specific six months of internship so that students really as a "quasi-professional" people accept the baptism of the enterprise.

\subsection{Construction of an Internship System}

SY college's system construction has always been weak. Basic management and punishment based on instructions or previous experience, did not institutionalize the management of each department. In short, many aspects are no institutional basis. Everyone is busy with daily work, and does not take the system construction as the guarantee basis for all work. SY management is more inclined to the "humanization" of management. The college should make relevant probation system, professional practice system, educational practice system, post practice system and related evaluation system according to the characteristics of running a college so as to institutionalize and standardize the practice management.

\subsection{Security of Internship Funds}

Independent colleges are self-financing nature. SY college can try multi-channel capital introduction and investment, for example, the college can consider the introduction of out-of-school enterprises and introduce part of the funds from enterprises. Enterprises can also reduce part of the enterprise employment costs according to the identity of college students "quasi-professional ". In-depth cooperation between the college and enterprises and reasonable planning can achieve" three wins "situation.

\subsection{Improvement of Internal Incentive System}

Human capital is indeed the biggest cost expenditure of the enterprise, but human capital has a great initiative. if reasonable development and utilization, it must produce value higher than the specific human cost.

According to Maslow's hierarchy of needs theory, Maslow's theory divides needs into five categories: Physiological needs, Safety need, Love and belonging, Esteem and Self-actualization. He arranged sequentially from lower to higher levels. After self-fulfilling, self-transcendence needs come out. Popular understanding: if one lacks food, safety, love and respect at the same time, the demand for food is usually the strongest, while other needs are less important. At this time the human consciousness is almost entirely occupied by hunger. All energy is used to get food. In these extreme circumstances, the whole point of life is to eat, Nothing else matters. Only when people are freed from physical need, more advanced, more social needs such as security are possible.[5] The cost of faculty spending in SY college is only $24 \%$ of the total cost of college spending. These include spending at the top and middle levels, It can be imagined that the average income level of other administrative staff and full-time teachers. What's more, SY college itself is far away downtown. According to Maslow's hierarchy of needs, SY college staff have been struggling on the first level. Without a good family background, they have to develop a second career or change jobs, On this background, How can they think more about the development of the college? Even if there is a moral standard of selfless dedication as a teacher, teachers are also ordinary people.

\subsection{Reduce Communication Costs}

There has been mistrust and mutual guessing among senior, middle, grass-roots and full-time staff. From them, they think the college is reluctant to invest inside, and the top puts most of the energy on the outside, as long as the inside is not messy. Under the influence of such universal consciousness, it is difficult for teachers to devote themselves to the development of their own teaching and scientific research. The middle level is basically younger and the title is low, and its own management experience is insufficient, so it is difficult to become a bridge for good communication between the grassroots and the senior level There is also a lack of unity of ideology between the high-level. As a college administrator or decision maker, we should first try to be consistent in college development, then inform staff of the blueprint for college development, then plan the college's infrastructure in batches, and finally work together to build the college's ultimate mission, not to make money more. 


\section{CONCLUSION}

Independent colleges are a product of the development of China's education. Students bear higher costs. If students do not have access to effective academic resources, whether from parents or students themselves, it is a pain. This paper obtains some problems and some suggestions from some ex-teachers of SY, hoping to provide references for its future development.

\section{ACKNOWLEDGMENTS}

This thesis was sponsored by one of the periodic results of 2017 Undergraduate Teaching Reform Project in Guangxi Higher Education for Research on Reform and Optimization of Teaching Operation Mechanism in Independent Colleges (2017JGB529).

\section{REFERENCES}

[1] Liu Renhong. Study on practice Teaching Optimization of accounting Major in Independent Colleges. [J]. Times Finance, 2019(33):116

[2] Nanning Normal University. School Profile. [EB/OL].http://www.nnnu.edu.cn/xygk/xyjj.html/

2020-6-08.

[3] Sun Ying. A Brief Analysis on the Training Mode of Applied Talents in Independent Colleges. [J] Education Modernization ,2018,5(39):29-30

[4] An Jiangying, Zhou Guozhu. Transformation from Entering to Integrating and from Docking to Service. $[\mathrm{EB} / \mathrm{OL}]$

http://www.jyb.cn/zgjyb/201807/t20180710_1146031.html 12020-06-08.

[5] China Science Communication. Maslow's Hierarchy of Needs.[EB/OL].

https://baike.baidu.com/item/\%E9\%A9\%AC\%E6\%96\%A F\%E6\%B4\%9B\%E9\%9C\%80\%Е6\%B1\%82\%Е5\%B1\%8 $2 \% \mathrm{E} 6 \%$ AC\%A1\%Е7\%90\%86\%Е8\%AE\%BA/11036498?f $\mathrm{r}=$ aladdin/2020-06-08. 